\title{
Pemahaman Konsep Sistem Koloid Hasil Pembelajaran Menggunakan Metode Diskusi Berbantuan LKS Pada Siswa Kelas XI SMA Negeri 1 Manuhing Tahun Ajaran 2017/2018
}

\author{
Awi*, Ruli Meiliawati, Sri Wahyutami \\ Program Studi Pendidikan Kimia, Jurusan Pendidikan MIPA, FKIP, Universitas \\ Palangka Raya, Indonesia \\ e-mail: awichemistry@gmail.com
}

Diterima: 02 Maret 2020; Disetujui: 16 Maret 2020; Diterbitkan: 21 Maret 2020

\begin{abstract}
ABSTRAK
Diskusi merupakan metode pembelajaran menggunakan percakapan ilmiah oleh beberapa orang yang tergabung dalam satu kelompok untuk saling bertukar pendapat tentang suatu topik masalah, atau sama-sama mencari pemacahan mendapatkan jawaban dan kebenaran suatu masalah. Tujuan penelitian ini adalah mendeskripsikan pemahaman konsep sistem koloid hasil pembelajaran menggunakan metode diskusi berbantuan LKS pada siswa kelas XI-IPA SMA Negeri 1 Manuhing Tahun Ajaran 2017/2018. Penelitian ini merupakan penelitian deskriptif. Subjek penelitian ini adalah siswa kelas XI IPA-2 SMA Negeri 1 Manuhing yang berjumlah 30 orang siswa. Instrumen yang digunakan berupa soal tes pemahaman konsep (pretes dan postes) berbentuk essay sebanyak 3 soal, lembar keterlaksanaan pembelajaran, lembar pengamatan aktivitas siswa dan angket respon siswa. Data pemahaman konsep diperoleh dari hasil tes tertulis berupa essay yang diberikan sebelum dan sesudah pembelajaran menggunakan metode diskusi berbantuan LKS. Hasil penelitian menunjukkan pemahaman konsep siswa pada kelas XI IPA SMA Negeri 1 Manuhing tahun ajaran 2017/2018 tentang sistem koloid setelah pembelajaran menggunakan metode diskusi berbantuan LKS rata-rata sebesar 81,5. Perubahan pemahaman konsep siswa pada setiap konsep sesudah pembelajaran menggunakan metode diskusi berbantuan LKS yaitu: (1) Menjelaskan perbedaan suspensi kasar, larutan sejati dan koloid sebesar 2,96\% menjadi sebesar 77,03\%; (2) Menjelaskan jenis-jenis koloid berdasarkan fese terdispersi dan fase pendispersi sebesar 4,44\% menjadi sebesar 69,62\%; (3) Menjelaskan sifat-sifat koloid (effek tyndall, gerak brown) sebesar $25 \%$ menjadi sebesar $100 \%$.
\end{abstract}

Kata kunci: metode diskusi, pemahaman konsep, sistem koloid

\section{PENDAHULUAN}

Undang-Undang Republik Indonesia No 20 Tahun 2003, Pendidikan adalah usaha sadar dan terencana untuk mewujudkan suasana belajar dan proses pembelajaran agar peserta didik secara aktif mengembangkan potensi dirinya untuk memiliki kekuatan spritual keagamaan, pengendalian diri, kepribadian, kecerdasan, ahlak mulia, serta ketrampilan yang diperlukan dirinya, masyarakat, bangsa, dan negara (Hasbullah, 2006). 
Undang-undang Nomor 20 Tahun 2003 tentang sistem Pendidikan Nasional menyebutkan, bahwa pendidikan nasional berfungsi mengembangkan kemampuan dan membentuk watak serta peradaban bangsa yang bermartabat dalam rangka mencerdaskan kehidupan bangsa. Pendidikan bertujuan untuk mengembangkan potensi peserta didik agar menjadi manusia yang beriman dan bertaqwa kepada Tuhan Yang Maha Esa, berahlak mulia, sehat, berilmu, cakap, kreatif, mandiri, dan menjadi warga Negara yang demokratis serta bertanggung jawab (Trianto, 2012).

Masalah utama dalam pembelajaran pada pendidikan formal (sekolah) dewasa adalah masih rendahnya daya serap peserta didik. Hal ini tampak dari realita hasil belajar peserta didik yang senantiasa masih sangat memprihatinkan. Presetasi ini tentunya merupakan hasil kondisi peserta didik itu sendiri, yaitu bagaimana sebenarnya belajar itu (belajar untuk beajar) dalam arti yang lebih substansial, bahwa proses pembelajaran hingga dewasa ini masih memberikan dominasi guru dan tidak memberikan akses bagi anak didik untuk berkembang secara mandiri melalui penemuan dan proses berpikirnya (Trianto, 2012). Penelitian tentang pemehaman konsep siswa dalam pembelajaran kimia sebelumnya juga telah dilakukan oleh Meliawati (2019) dan Valentie (2019).

Berdasarkan hasil penelitian terhadap rendahnya hasil belajar peserta didik disebabkan dominannya proses pembelajaran konvensional. Suasana kelas cenderung teaher-centered sehingga siswa menjadi pasif. Meskipun demikian, guru lebih suka menerapkan model tersebut, sebab tidak memerlukan alat dan bahan praktik, cukup menjelaskan konsep-konsep yang ada pada buku ajar atau referensi lain. Dalam hal ini, siswa diajarkan strategi belajar yang dapat memahami bagaimana belajar, berpikir, dan motivasi diri sendiri (self motivation), padahal aspek-aspek tersebut merupakan kunci keberhasilan dalam suatu pembelajaran. Masalah ini banyak dijumpai dalam kegiatan proses belajar mengajar dikelas, oleh karena itu, perlu diterapkan suatu strategi belajar yang dapat membantu siswa untuk memahami materi ajar dan aplikasi serta relevansinya dalam kehidupan sehari-hari (Trianto, 2012).

Motivasi belajar merupakan pendorong anak serta didik untuk belajar. Motivasi timbul karena adanya keinginan atau kebutuhan dalam diri seseorang. Seseorang berhasil dalam belajar karena ia ingin belajar. Menurut Winkle, motivasi belajar adalah keseluruhan daya penggerak pada diri siswa yang menimbulkan kegiatan belajar, yang menjamin kelangsungan belajar dan yang memberi arah pada kegiatan belajar. Oleh karena itu, tujuan yang dikehendaki oleh siswa dapat tercapai. Motivasi belajar merupakan faktor psikis yang bersifat nonintelektual. Perannya yang khas adalah dalam memberikan gairah atau semangat belajar, siswa yang termotivasi kuat akan mempunyai banyak energi untuk melakukan kegiatan belajar (Tatang, 2012).

Salah satu pokok bahasan yang dipelajari siswa SMA kelas XI adalah sistem koloid. Materi ini biasanya diajarkan guru dengan menggunakan metode ceramah sehingga siswa kurang aktif, merasa jenuh, dan bosan belajar di dalam kelas. Guru diharapkan mampu menentukan model/metode pembelajaran yang tepat untuk dapat memotivasikan siswa dalam meningkatkan hasil belajar dan kreatifitas siswa selama kegiatan belajar mengajar berlangsung.

Hasil penelitian Elfrida (2017) tentang pemahaman konsep penyetaraan reaksi reduksi oksidasi dengan cara perubahan bilangan oksidasi pasca 
pembelajaran menggunakan metode diskusi berbantuan LKS. Berdasarkan hasil penelitiannya menyatakan bahwa pembelajaran menggunakan metode diskusi berbantuan LKS mampu meningkatkan pemahaman konsep siswa.

Pembelajaran menggunakan metode diskusi berbantuan LKS dapat dilakukan untuk membantu siswa dalam memahami konsep sistem koloid, dimana siswa diajak untuk berperan aktif dalam pembelajaran. LKS yang digunakan juga diharapkan dapat membantu siswa sebagai alat bantu untuk memperoleh pemahaman.

Berdasarkan uraian diatas, peneliti tertarik untuk melakukan penelitian yang berjudul "PemahamanKonsep Sistem koloid Hasil Pembelajaran menggunakan MetodeDiskusi Berbantuan LKS pada siswa kelas XI-IPA SMA Negeri 1 Manuhing Tahun Ajaran 2017/2018”.

\section{METODOLOGI PENELITIAN}

Penelitian ini merupakan penelitian deskriptif, penelitian deskriptif (descriptive research) yaitu suatu penelitian yang diupayakan untuk mencandra atau mengamati permasaahan secara sistematis dan akurat mengenai fakta dan sifat objek tertentu. Penelitian deskriptif ditujukan untuk memaparkan, menggambarkan, dan memetakan fakta-fakta berdasarkan cara pandang atau kerangka berpikir tertentu (Mahmud, 2011).

Melalui penelitian ini peneliti berusaha memecahkan masalah sesuai dengan tujuan penelitian ini, maka peneliti mendeskripsikan pemahaman konsep sistem koloid hasil pembelajaran menggunakan metode diskusi berbantuan LKS pada siswa kelas XI IPA SMA Negeri 1Manuhing tahun ajaran 2017/2018.

Penelitian dilaksanakan di SMA Negeri 1 Manuhing yang beralamat di Jl. Negara No. 48 Kecematan Mahuning, Kabupaten Gunung Mas, Provinsi Kalimantan Tengah. Waktu penelitian ini dilakukan sejak Mei 2018 yang merupakan waktu pengambilan data dan kan dilanjutkan dengan menganalisis data jika semua data terkumpul. Objek penelitian ini adalah siswa kelas XI IPA SMA Negeri 1 Manuhing Tahun Ajaran 2017/2018 sebanyak 30 orang siswa.

Data pada penelitian ini berupa data pemahaman konsep siswa, pengelolaan pembelajaram, aktivitas dalam pembelajaran. Data yang diperoleh dan tehnik pengambilan data dapat dipapar pada Tabel 1 .

Tabel 1. Teknik Pengumpulan Data

\begin{tabular}{lll}
\hline Data Yang Diperoleh & Teknik Pengumpulan Data & \multicolumn{1}{c}{ Instrumen } \\
\hline Pemahaman konsep & Memberikan soal tes & soal tes pemahaman \\
siswa & pemahaman konsep (pretes dan & konsep (pretes dan \\
postes) & postes) \\
Pengelolaan & Mengamati aktivitas guru pada & Lembar pengamatan \\
pembelajaran & saat pembelajaran & pengelolaan \\
& menggunakan metode diskusi & pembelajaran \\
berbantuan LKS & \\
Aktivitas siswa dalam & Melakukan pengamatan & Lembar pengamatan \\
pembelajaran & aktivitas siswa secara & aktivitas siswa secara \\
& kelompok & kelompok \\
Respon siswa & Memberikan angket respon & Lembar angket siswa \\
& siswa & \\
\hline
\end{tabular}




\section{HASIL PENELITIAN DAN PEMBAHASAN}

Peningkatan pemahaman konsep didasarkan pada data hasil pretes dan postes siswa. Butir soal pada saat pretes dan postes mewakili konsep-konsep Sistem Koloid adalah sebanyak 3 butir soal, dimana setiap butir soal pretes dan postes memiliki kriteria penskoran. Skor maksimum yang diperoleh siswa adalah sebanyak 10. Total skor yang didapat siswa dikonversikan dalam bentuk presentase dan kemudian diklasifikasikan tingkat pemahaman siswa. Pemahaman konsep siswa pada setiap indikator dapat ditelusuri dengan menganalisis pola jawaban dalam hasil pekerjaan siswa dari pretes dan postes. Kriteria perubahan pemahaman konsep siswa setiap indikator dapat dilihat pada Tabel 2.

Tabel 2. Peningkatan Pemahaman Konsep

\begin{tabular}{cccccc}
\hline Indikator & Butir Soal & \multicolumn{2}{c}{ Pemahaman Konsep (\%) } & Gain & $\begin{array}{c}\text { Peningkatan } \\
\text { Pemahaman } \\
\text { Konsep }\end{array}$ \\
\cline { 3 - 4 } & & Pretes & Postes & & 76,3 \\
I & 1 & 2,96 & 77,03 & 0,763 & 68,2 \\
II & 2 & 4,44 & 69,62 & 0,682 & 100 \\
III & 3 & 25 & 100 & 1 & 81,5 \\
Rata-rata & & 10,8 & 82,1 & & \\
\hline
\end{tabular}

Tabel 2 menunjukan presentase pemahaman konsep dapat dilihat dari selisish skor pretes dan postes siswa. berdasarkan tabel 14 diketahui bahwa seluruh siswa memperoleh presentase pemahaman konsep pada postes lebih besar dari pada presentase pretes. Artinya, setelah siswa mengikuti pembelajaran menggunakan model diskusi berbantuan LKS mempengaruhi perubahan konsep siswa terhadap materi sistem koloid.

Peningkatan pemahaman konsep siswa pada indikator I yaitu pemahaman konsep menjelaskan perbedaan suspensi kasar, larutan sejati dan koloid sebesar 76,3. Peningkatan konsep siswa pada indikator II yaitu menjelaskan jenis-jenis koloid sebesar 68,2. Peningkatan pemahaman konsep siswa pada indikator III yaitu menjelaskan sifat-sifat koloid sebesar 100.

Peningkatan pemahaman konsep paling rendah dari ketiga indikator tersebut adalah pada indikator dua dengan presentase peningkatan pemahaman konsep 68,2. Rendahnya peningkatan pemahaman konsep siswa pada indikator dua Karena banyak siswa yang hanya dapat menjelaskan jenis-jenis koloid tanpa memberikan contohnya. Hal tersebut disebabkan oleh siswa yang tidak dapat memahami dengan baik soal yang diberikan.

Peningkatan pemaman konsep yang paling tinggi dari ketiga indikator tersebut adalah indikator tiga yaitu menjelaskan sifat-sifat koloid dengan kategori sangat tinggi dan presentase peningkatan pemahaman konsep sebesar 100 . Tingginya peningkatan pemahaman konsep siswa pada indikator tiga karena banyak siswa yang dapat menjelaskan sifat-sifat kooid. Hal tersebut disebabkan karena siswa mengingat bahwa sifat koloid sifatnya cahaya.

Secara keseluruhan presentase pemahaman konsep siswa pada materi Sistem Koloid saat pretes dan postes berturut-turut adalah 10,8\% dan 82,1\% dari presentase tersebut terjadi peningkatan pemahaman konsep dari kurang menjadi sangat baik. Adapun besarnya peningkatan pemahaman siswa hasil pembelajaran yang diperoleh dari selisih presentase pretes dan postes pada keseluruhan 
indikator adalah $81,5 \%$. Hal ini menunjukan bahwa pembelajaran menggunakan metode diskusi berbantuan LKS mampu meningkatkan pemahaman konsep siswa terhadap materi Sistem Koloid. Grafik besarnya presentase pemahaman konsep siswa pada saat pretes dan postes untuk setiap indikator dapat dilihat pada Gambar 1.

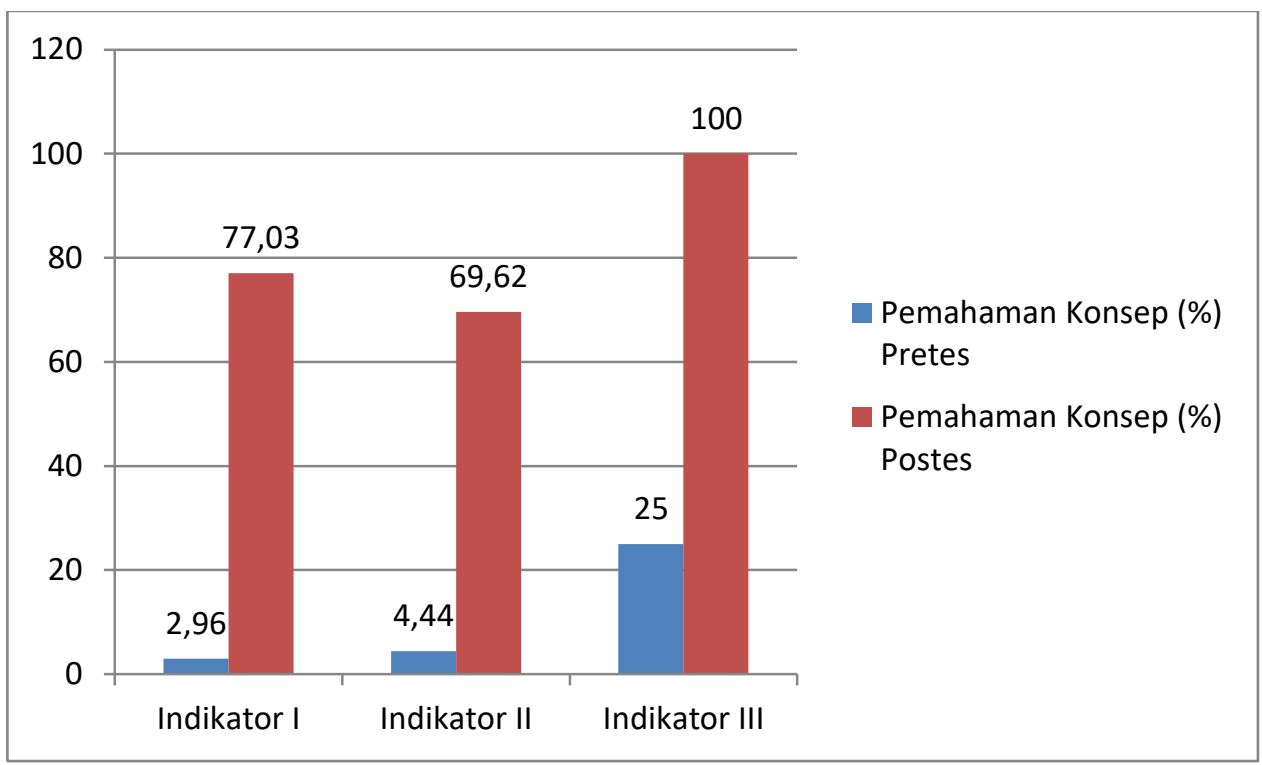

Ganbar 1. Grafik Presentase Pemahaman Konsep Siswa per Indikator

Gambar 1 menunjukan grafik pemahamn konsep siswa per indikator. presentase masing-masing indikator saat pretes lebih kecil dari pada presentase masing-masing indikator pada saat postes. Perubahaan pemahaman konsep dari pret ke postes tersebut menunjukan terjadinya peningkatan pemahaman konsep dari pretes ke postes tersebut menunjukan terjadinya peningkatan pemahaman pada masing-masing indikator.

Peningkatan skor postes siswa dimulai dengan nilai tertinggi hingga ke terendah disajikan pada tabel 15 terhadap KBM dapat digambarkan dalam sebuah kurva. Kurva nilai pretes dan postes terhadap KBM menunjukan tingkat ketuntasan siswa disajikan pada Gambar 2.

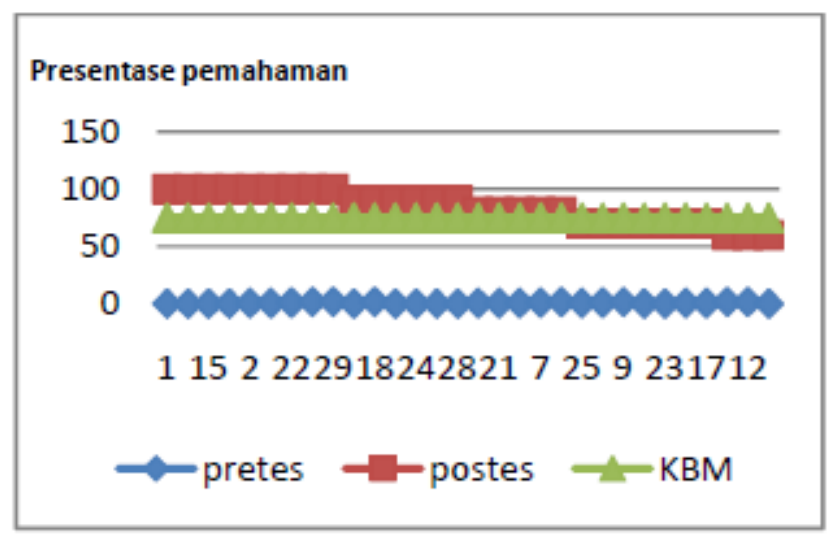

Gambar 2. Kurva Nilai Pretes Dan Postes Terhadap KBM 
Gambar 2 merupakan kurva nilai siswa pada pretes dan postes terhadap KBM yang menunjukan pembelajaran menggunakan model diskusi berbantuan LKS dapat merubah pemahamn siswa menjadi meningkat. Kurva menunjukan hasil pembelajaran menggunakan model diskusi berbantuan LKS mengalami peningkatan pemahaman dari pretes ke postes, nilai siswa pada saat pretes termasuk kategori rendah yang dimana siswa memperoleh nilai 0 setelah postes nilainya mengalami peningkatan dengan kata lain bahwa siswa mengalami peningkatan pemahaman walaupun sebanyak 12 orang siswa nilainya masih belum mencapai KBM yaitu kurang dari 75 .

Perubahan pemahaman konsep siswa pada materi sistem koloid dianalisis berdasarkan hasil pretes dan postes pada setiap indikator. Pretes dan postes merupakan tes pemahaman konsep yang diberikan untuk mengetahui konsep pemahaman siswa setelah pembelajaran menggunakan model diskusi berbantuan LKS. Berikut ini analisis pemahaman konsep siswa pada setiap indikator yang dianalisis dari hasil jawaban pretes dan postes.

Pemahamahan konsep siswa pada indikator 1 dari jawaban butir soal 1 . Skor menunjukan sejauh mana kemampuan siswa dalam mengklasifikasikan sistem koloid berdasarkan hasil percobaan yang ditelusuri pada soal nomor 1 dapat diihat pada Tabel 3.

Tabel 3. Deskripsi Pemahaman dan Skor Jawaban Siswa Pada Butir Soal 1

\begin{tabular}{|c|c|}
\hline Dekripsi Pemahaman & Skor \\
\hline $\begin{array}{l}\text { Siswa tidak memahami, tidak ada jawaban atau jawaban yang tidak } \\
\text { relevan }\end{array}$ & 0 \\
\hline $\begin{array}{l}\text { Siswa dapat menjelaskan perbedaan suspensi kasar, larutan sejati } \\
\text { dan koloid tanpa contoh }\end{array}$ & 1 \\
\hline $\begin{array}{l}\text { Siswa dapat menjelaskan perbedaan suspensi kasar atau larutan } \\
\text { sejati atau koloid serta contohnya }\end{array}$ & 1,5 \\
\hline $\begin{array}{l}\text { Siswa dapat membedakan anatara suspensi kasar dengan larutan } \\
\text { sejati, koloid dengan larutan sejati, dan suspensi kasar dengan } \\
\text { koloid tanpa contoh }\end{array}$ & 2 \\
\hline $\begin{array}{l}\text { Siswa dapat membedakan anatara suspensi kasar dengan larutan } \\
\text { sejati, koloid dengan larutan sejati, dan suspensi kasar dengan } \\
\text { koloid satu contoh }\end{array}$ & 2,5 \\
\hline $\begin{array}{l}\text { Siswa dapat membedakan anatra suspensi kasar dengan larutan } \\
\text { sejati, koloid dengan larutan sejati, dan suspensi kasar dengan } \\
\text { koloid dua contoh }\end{array}$ & 3 \\
\hline $\begin{array}{l}\text { Siswa dapat menjelaskan membedakan suspensi kasar, larutan } \\
\text { sejati, koloid tanpa contoh }\end{array}$ & 3 \\
\hline $\begin{array}{l}\text { Siswa dapat menjelaskan membedakan suspensi kasar, larutan } \\
\text { sejati, koloid satu contoh }\end{array}$ & 3,5 \\
\hline $\begin{array}{l}\text { Siswa dapat menjelaskan membedakan suspensi kasar, larutan } \\
\text { sejati, koloid dua contoh }\end{array}$ & 4 \\
\hline $\begin{array}{l}\text { Siswa dapat menjelaskan perbedaan suspensi kasar, larutan sejati } \\
\text { dan koloid beserta contohnya }\end{array}$ & 4,5 \\
\hline
\end{tabular}


Pemahaman siswa untuk indikator I pada pretes yaitu 2,96\% kemudian meningkat pada saat postes menjadi $77,03 \%$ dari hasil presentase tersebut dapat dikatakan peningkatan pemahaman siswa sebesar $76,3 \%$ setelah pembelajaran menggunakan model diskusi berbantuan LKS.

Berdasarkan deskripsi pemahaman konsep dan skor hasil jawaban siswa pada Tabel 3 maka didapatkan hasil pengamatan jawaban pretes dan postes untuk mengetahui adanya perubahan skor yang diamati siswa. Berikuti ini dipaparkan perubahan skor jawaban siswa pada nilai untuk menjelaskan perbedaan suspensi kasar, larutan sejati, dan koloid. Perubahan skor pada dalam Tabel 4, menunjukan bahwa pemahaman siswa meningkat dari pretes ke postes. Berikut tabel perubahan skor jawaban siswa pada soal nomor 1 .

Tabel 4. Perubahan Skor Jawaban Siswa Dalam Menjelaskan perbedaan Suspensi Kasar, Larutan Sejati, Dan Koloid

\begin{tabular}{|c|c|c|c|c|}
\hline \multicolumn{2}{|r|}{ Pretes } & \multicolumn{2}{|c|}{ Postes } & \multirow[t]{2}{*}{$(\%)$} \\
\hline Skor & Jumlah Siswa & Skor & Jumlah Siswa & \\
\hline \multirow{6}{*}{0} & \multirow{6}{*}{26} & 2 & 2 & 6,67 \\
\hline & & 2,5 & 4 & 13,33 \\
\hline & & 3 & 3 & 10 \\
\hline & & 3,5 & 3 & 10 \\
\hline & & 4 & 4 & 13,33 \\
\hline & & 4,5 & 10 & 13,33 \\
\hline \multirow{3}{*}{1} & \multirow{3}{*}{4} & 1 & 1 & 33,33 \\
\hline & & 2 & 2 & 6,67 \\
\hline & & 3 & 1 & 3,33 \\
\hline
\end{tabular}

Tabel 4 menunjukan bahwa pada saat postes terdapt 10 siswa yang dominan ke skor 4,5. Pemahaman konsep siswa tentang mengklasifikasikan sistem koloid berdasarkan hasil percobaan, sebanyak 10 orang siswa mengalami perubahan pemahaman konsep.

Tabel 5. Menunjukan sebanyak 33,33\% (10 siswa) yang memperoleh skor 0 ke skor 4,5, Pemahaman konsep siswa tentang mengklasifikasikan sistem koloid berdasarkan hasil percobaan, sebanyak 10 orang siswa mengalami perubahan pemahaman konsep.

Siswa nomor 2 menegaskan bahwa pada saat pretes sebagian besar siswa belum dapat menjelaskan perbedaan suspensi kasar, larutan sejati dan koloid berdasarkan data percobaan, setelah percobaan pembelajaran menggunakan metode diskusi berbantuan LKS maka pada postes siswa sudah dapat menjelaskan perbedaan suspensi kasar, larautan sejati dan koloid berdasarkan data percobaan, sebanyak 10 orang siswa mengalami perubahan pemahaman konsep. Siswa nomor 2 adalah siswa terpilih menjadi perwakilan perubahan pemahaman konsep dari skor 0 ke skor 4,5 .

Siswa nomor 2 untuk soal nomor 1 siswa tidak memberikan jawaban atau lembar jawaban kosong, karena siswa tidak dapat dalam membedakan suspensi kasar, larutan sejati dan koloid, dimana siswa tersebut tidak memberikan jawaban atau lembaran kosong sehingga siswa memperoleh skor 0 , sedangkan postes siswa mengalami perubahan pemahaman konsep, siswa mampu menjelaskan perbedaan suspensi kasar, larutan sejati dan koloid sehingga memperoleh skor 4,5. 
Siswa memiliki kemampuan memahami konsep saat postes setelah siswa mengikuti pembelajaran menggunakan metode diskusi berbantuan LKS, Setelah pembelajaran dengan menggunakan metode diskusi berbantuan LKS siswa memperoleh skor 4,5 yaitu siswa yang dapat menjelaskan perbedaan suspensi kasar, larutan sejati dan koloid dengan benar. Siswa mengalami perubahan memahami konsep setelah siswa mengikuti pembelajaran menggunakan metode diskusi.

Siswa berdiskusi untuk menjelaskan perbedaan supensi kasar, larutan sejati dan koloid dengan teman sekelompoknya sehingga mengalami perubahan pemahaman konsep siswa. Manfaat menggunakan metodediskusi berbantuan LKS ini pada kegiatan pembelajaran dimaksud agar siswa dapat memahami prinsif dan konsep secara mandiri dan melatih kemampuan siswa berpikir, membangkitkan motivasi dan minat siswa dan membantu siswa untuk saling bertukar pendapat kepada teman-teman sekelompoknya.

Terlihat pada jawaban Lembar Kerja Siswa (LKS), siswa berdiskusi menjawab LKS dari hasil pengamatan ekprerimen untuk mengetahui perbedaan antara suspensi kasar, larutan sejati. Siswa nomor 2 adalah perwakilan siswa yang mengalami perubahan skor 0 ke skor 4,5 dan siswa sudah dapat mengerjakan LKS (Lembar Kerja Siswa), siswa terlihat aktif pada saat melakukan percobaan, berdiskusi, bekerjasama dengan teman satu kelompoknya pada saat mengerjakan LKS.

Pemahaman konsep siswa pada indikator 2 ditelusuri dari jawaban butir soal 2. Skor menunjukan sejauh mana kemampuan siswa dalam mengklasifikasikan jenis-jenis koloid berdasarkan fase terdispersi dan fase pendispersinya berdasarkan hasil data percobaan dinilai dari butir soal 2 dengan kriteria penilaian pretes dan postes dilihat pada Tabel 5.

Tabel 5. Deskripsi Pemahaman dan Skor Jawaban Siswa Pada Butir Soal 2

\begin{tabular}{lc}
\hline \multicolumn{1}{c}{ Dekripsi Pemahaman } & Skor \\
\hline $\begin{array}{l}\text { Siswa tidak memahami, tidak ada jawaban atau jawaban yang tidak } \\
\text { relevan }\end{array}$ & 0 \\
$\begin{array}{l}\text { Siswa dapat menjelaskan sol atau emulsi atau buih saja, tanpa } \\
\text { contoh }\end{array}$ & 1 \\
$\begin{array}{l}\text { Siswa dapat menjelaskan sol atau emulsi atau buih saja, serta } \\
\text { contoh }\end{array}$ & 1,5 \\
Siswa dapat menjelaskan sol dengan emulsi, atau emulsi dengan & 2 \\
buih, atau buih dengan sol tanpa contoh & \\
Siswa dapat menjelaskan sol dengan emulsi, atau emulsi dengan & 2,5 \\
buih, atau buih dengan sol satu contoh & 3 \\
$\begin{array}{l}\text { Siswa dapat menjelaskan sol dengan emulsi, atau emulsi dengan } \\
\text { buih, atau buih dengan sol dua contoh }\end{array}$ & 3 \\
Siswa dapat menjelaskan sol, emulsi dan buih tanpa contoh & 3 \\
Siswa dapat menjelaskan sol, emulsi dan buih serta satu contoh & 3,5 \\
Siswa dapat menjelaskan sol, emulsi dan buih serta dua contoh & 4 \\
Siswa dapat menjelaskan sol, emulsi dan buih beserta contohnya & 4,5 \\
\hline
\end{tabular}

Pemahaman siswa untuk indikator 2 pada pretes yaitu $4,44 \%$ kemudian meningkat pada saat postes menjadi $69,62 \%$, dari hasil presentase tersebut dapat 
dikatakan bahwa terjadi perubahan pemahaman konsep siswa dari pretes ke postes setelah pembelajaran menggunkan metode diskusi berbantuan LKS. Berikut tabel perubahan skor jawaban siswa pada Butir Soal 2. Berikut ini dipaparkan peningkatan skor jawaban siswa pada nilai dalam menjelaskan jenis-jenis koloid berdasarkan fase terdispersi dan fase pendispersinya dalam Tabel 6.

Tabel 6. Perubahan Skor Jawaban Siswa PadaIndikator Mengklasifikasikan JenisJenis Koloid Berdasarkan Fase Terdispersi Dan Fase Pendispersinya

\begin{tabular}{|c|c|c|c|c|}
\hline \multicolumn{2}{|c|}{ Pretes } & \multicolumn{2}{|r|}{ Postes } & \multirow[t]{2}{*}{$(\%)$} \\
\hline Skor & Jumlah Siswa & Skor & Jumlah Siswa & \\
\hline \multirow{5}{*}{0} & \multirow{5}{*}{24} & 2,5 & 1 & 3,33 \\
\hline & & 3 & 5 & 16,67 \\
\hline & & 3,5 & 3 & 10 \\
\hline & & 4 & 4 & 13,33 \\
\hline & & 4,5 & 11 & 36,67 \\
\hline \multirow{4}{*}{1} & \multirow{4}{*}{6} & 2,5 & 1 & 3,33 \\
\hline & & 3 & 1 & 3,33 \\
\hline & & 3,5 & 1 & 3,33 \\
\hline & & 4 & 3 & 10 \\
\hline
\end{tabular}

Data pada Tabel 6 menunjukan bahwa pada saat postes terdapat 11 orang siswa dominan mendapatkan skor 0 ke skor 4,5 pada indikator 2 dalam menjelaskan jenis-jenis koloid.

Pemahaman konsep siswa dalam mengklasifikasikan jenis-jenis koloid, sebanyak 11 orang siswa mengalami perubahan pemahaman konsep. Siswa dengan nomor 5 adalah siswa yang terpilih menjadi perwakilan perubahan pemahaman konsep dari skor 0 ke skor 4,5. Siswa dengan nomor 5 mengalami perubahan pemahaman dimana pada saat pretes siswa tidak menuliskan dan menjelaskan jenisjenis koloid, hal ini karena siswa belum memahami maksud soal dan belum pernah mendapatkan materi sistem koloid sebelumnya sedangkan pada saat postes siswa dapat menjelaskan jenis-jenis koloid sehingga memperoleh skor 4,5 .

Siswa nomor 3 mengalami perubahan pemahaman dari skor 0 (pretes) ke skor 4,5 (postes) dimana pada saat pretes siswa tidak dapat mengklasifikasikan jenis-jenis koloid, karena siswa belum pernah mendapatkan materi sistem koloid sebelumnya sedangkan pada saat postes siswa dapat mengklasifikasikan jenisjenis koloid sehingga memperoleh skor 4,5.

Siswa memiliki kemampuan memahami konsep saat postes setelah siswa mengikuti pembelajaran menggunakan metode diskusi berbantuan LKS. Setelah pembelajaran dengan menggunakan metode diskusi berbantuan LKS siswa memperoleh skor 1 yaitu siswa yang dapat menjelaskan jenis-jenis koloid. Siswa memiliki kemampuan memahami konsep saat postes setelah siswa mengikuti pembelajaran menggunakan metode diskusi berbantuan LKS.

Siswa berdiskusi untuk menjelaskan pengertian jenis-jenis koloid dengan teman sekelompoknya sehingga mengalami perubahan pemahaman konsep siswa. Manfaat menggunakan metode diskusi berbantuan LKS ini pada kegiatan pembelajaran agar siswa dapat memahami prinsif dan konsep secara mandiri dan melatih kemampuan siswa berpikir, membangkitkan motivasi dan minat siswa dan 
membantu siswa untuk saling bertukar pendapat kepada teman-teman sekelompoknya. Terlihat pada jawaban Lembar Kerja Siswa (LKS), siswa berdiskusi menjawab LKS dari hasil pengamatan ekprerimen untuk mengetahui pengertian jenis-jenis koloid.

Siswa nomor 3 yang mengalami perubahan skor 0 ke skor 4,5, siswa dengan nomor 3 tersebut sudah dapat mengerjakan LKS (Lembar Kerja Siswa) menggunakan metode diskusi berbantuan LKS dengan benar, siswa terlihat aktip pada saat melakukan percobaan, berdiskusi, kerjasama dengan teman satu kelompoknya pada saat mengerjakan LKS. Hal ini menandakan bahwa siswa mengaitkan konsep perancangan langkahlangkah eksperimen sehingga siswa dapat mengklasifikasikan jenis-jenis koloid sudah baik.

Perubahan pemahaman konsep Dalam Menjelaskan Sifat-Sifat Koloid (Effek Tyndall, Gerak Brown) ditelusuri pada soal nonor 3 dengan deskripsi pemahaman konsep siswa untuk soal nomor 3 disajikan pada Tabel 7.

Tabel 7 Deskripsi Pemahaman Konsep Dalam Menjelaskan Sifat-Sifat Koloid (Effek Tyndall, Gerak Brown)

\begin{tabular}{lc}
\multicolumn{1}{c}{ Dekripsi Pemahaman } & Skor \\
\hline Siswa tidakmemahamikonsep (tidakadajawabanataujawabansalah) & 0 \\
Siswa dapat menjelaskan efek Tyndall atau gerak Brown & 0,5 \\
Siswa dapat menjelaskan efek Tyndall dan gerak Brown & 1 \\
\hline
\end{tabular}

Berdasarkan deskripsi pemahaman konsep dan skor hasil dan jawaban siswa pada Tabel 7 maka didapatkan hasil dari pengamatan jawaban pretes dan postes untuk mengetahui adanya perubahan skor yang diamati siswa. Perubahan skor pada Tabel 7 menunjukan bahwa pemahaman siswa mengalami perubahan pemehaman konsep dari pretes ke postes. Berikut ini dipaparkan perubahan skor jawaban siswa pada nilai dalam menjelaskan sifat-sifat koloid (effek tyndall, gerak brown) dalam Tabel 8.

Tabel 8. Menunjukan perubahan skor jawaban siswa pada indikator 3 dalam menjelaskan sifat-sifat koloid (Effek Tyndall, Gerak Brown).

\begin{tabular}{|c|c|c|c|c|}
\hline \multicolumn{2}{|c|}{ Pretes } & \multicolumn{2}{|r|}{ Postes } & \multirow[t]{2}{*}{$(\%)$} \\
\hline Skor & Jumlah Siswa & Skor & Jumlah Siswa & \\
\hline \multirow{2}{*}{0} & \multirow{2}{*}{15} & 0,5 & $x$ & - \\
\hline & & 1 & 15 & 50 \\
\hline \multirow[t]{2}{*}{0,5} & 15 & 0,5 & 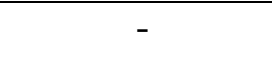 & - \\
\hline & & 1 & 15 & 50 \\
\hline
\end{tabular}

Tabel 8 menunjukan perubahan pemahaman siswa pada saat postes sebanyak 15 orang siswa (50\%) memperoleh skor 0 ke skor 1 yang membuktikan terjadi perubahan pemahaman konsep pada siswa.

Tabel 8 menunjukkan sebanyak 50\% (15 siswa) yang memperoleh skor 0 ke skor 1, hal tersebut menandakan bahwa siswa mengalami perubahan pemahaman konsep setelah pembelajaran menggunakan metode diskusi berbantuan LKS.

Siswa nomor 21 yang menjadi perwakilan dari siswa yang mengalami perubahan pemahaman konsep dari skor 0 yaitu siswa yang tidak memberikan 
jawaban atau lembar jawaban kosong, hal ini dapat disebabkan karena siswa tidak dapat menjelaskan sifat-sifat koloid sehingga siswa lebih memilih tidak memberikan jawaban terhadap pertanyaan yang diajukan pada soal pretes.

Setelah pembelajaran menggunakan metode diskusi berbantuan LKS siswa memperoleh skor 1 yaitu siswa yang mampu menjelaskan sifat-sifat koloid. Siswa memiliki kemampuan memahami konsep saat postes setalah siswa mengikuti pembelajaran menggunakan metode diskusi berbantuan LKS, Setelah pembelajaran dengan menggunakan model diskusi berbantuan LKS siswa memperoleh skor 1 yaitu siswa yang dapat menjelaskan sifat-sifat koloid. Siswa memiliki kemampuan memahami konsep saat postes setelah siswa mengikuti pembelajaran menggunakan metode diskusi berbantuan LKS. Siswa berdiskusi untuk menjelaskan sifat-sifat koloid dengan teman sekelompoknya sehingga mengalami perubahan pemahaman konsep siswa. Manfaat menggunakan metode diskusi berbantuan LKS ini pada kegiatan pembelajaran agar siswa dapat memahami prinsif dan konsep secara mandiri dan melatih kemampuan siswa berpikir, membangkitkan motivasi dan minat siswa dan membantu siswa untuk saling bertukar pendapat kepada teman-teman sekelompoknya.

Terlihat pada jawaban Lembar Kerja Siswa (LKS), siswa berdiskusi menjawab LKS dari hasil pengamatan ekprerimen untuk menjelaskan jenis-jenis koloid. Siswa dengan nomor 21 sudah dapat mengerjakan LKS (Lembar Kerja Siswa) dengan menggunakan metode diskusi berbantuan LKS dengan benar, siswa terlihat aktip pada saat melakukan percobaan, berdiskusi, kerjasama dengan teman satu kelompoknya pada saat mengerjakan LKS. Hal ini menandakan bahwa siswa mengaitkan konsep perancangan langkah-langkah eksperimen sehingga siswa dapat mengklasifikasikan sifat-sifat koloid sudah baik.

\section{SIMPULAN}

Kesimpulan penelitian tentang pemahaman konsep Sistem Koloid Hasil Pembelajaran Menggunakan Metode Diskusi Berbantuan LKS pada siswa kelas XI IPA SMA Negeri 1 Manuhing Tahun Ajaran 2017/2018, maka ditarik kesimpulan sebagai berikut: (1) Menjelaskan perbedaan suspensi kasar, larutan sejati dan koloid, mengalami perubahan sebesar $2,96 \%$ menjadi $77,03 \%$, terjadi peningkatan berdasarkan rumus Gain sebesar 0,76. (2) Menjelaskan jenis-jenis koloid berdasarkan fese terdispersi dan fase pendispersi mengalami perubahan sebesar $4,44 \%$ menjadi $69,62 \%$, terjadi peningkatan berdasarkan rumus Gain sebesar 0,68. (3) Menjelaskan sifat-sifat koloid (effek tyndall, gerak brown) dan sebelum pembelajaran siswa tidak memiliki pemahaman, setelah pembelajaran sebesar $25 \%$ menjadi $100 \%$, terjadi peningkatan berdasarkan rumus Gain sebesar 1. (4) Rata-rata pemahaman konsep siswa kelas XI IPA SMA Negeri 1 Manuhing tahun ajaran 2017/2018 setelah pembelajaran menggunakan metode diskusi berbantuan LKS adalah sebesar 81,5.

\section{DAFTAR PUSTAKA}

Arfrilianto, M. 2012. Peningkatan Pemahaman Konsep dan Kompetensi Strategi Matematis Siswa SMA dengan Menggunakan Pendekatan Methaphorica Thinking. Jurnal ilmiah program studi pendidikan matematikan, 1 (2): diunduh pada 31 Agustus 2019, dari http:// www.academia.edu

Dadar, R.W. 2011. Teori-teori Belajar dan Pembelajaran. Jakarta: Erlangga 
Depertemen Pendidikan Nasional. 2003.

Kurikulum 2006 SMA Pedoman Khusus Pengerbangan Silabus Dan Penilaian Mata Pelajaran Kimia. Depertemen Pendidikan Nasional, Direktorat Jendal Pendidikan Dasar Dan Menengah, Direktorat Pendidikan Menengah Umum, Bagian Proyek Pengembangan Pendidikan Berorientasi Kecakapan Hidup PMU.

Elfrida. 2017. Pemahaman Konsep Penyeteraan Reaksi Reduksi Oksidasi dengan Cara Perubahan Bilanagan Oksidasi Pasca Pembelajaran Menggunakan Metode Diskusi Berbantuan LKS Pada Siswa Kelas XII SMA Kristen Palangka Raya Tahun Ajaran 2016/2017. Skripsi. Tidak diterbitkan: Universitas Palangka Raya.

Hasbullah. 2006. Dasar-dara Ilmu Pendidikan. Jakarta: PT Raja Grafindo .

Persada Hamdani. 2011. Strategi Belajar Mengajar. Bandung : Pustaka Setia. Hamruni. 2012. Strategi Pembeajaran. Yogyakarta: Insan Mandiri.

Meiliawati, R. 2019. Pemahaman Konsep Sifat Jari-Jari Atom Dan Keelektronegatifan Pada Mahasiswa Pendidikan Kimia Semester IV Tahun Ajaran 2016/2017 Hasil Pembelajaran Menggunakan Model Discovery Learning. Jurnal Ilmiah Kanderang Tingang. 10, 1 (Jun. 2019), 38-45.

Miftahu, H. 2013. Model-model Pembelajaran dan Pembelajaran. Yogyakarta: Pustaka Pelajar.

Iskandarwassid. 2011. Strategi Pembelajaran Bahasa. Bandung: PT. Remaja Rosdakarya.

Sudjana, Nana. 2014. Dasar-dasar Proses Belajar Mengajar. Bandung: Sinar Baru Algesindo.

Suyanti, D. Retno. 2010. Strategi Pembelajaran Kimia. Yogyakarta: Graha Ilmu.

Kunandar. 2014. Penilaian Autentik (Penilaian hasil belajar peserta didik berdsarkan kurikulum 2013) suatu pendekatan praktik diserati contoh Edisi revisi. Depok : Rajagrafindo persada.

Rusman. 2010. Model-Model Pembelajaran Mengembangkan Profesionalisme Guru. Jakarta: Rajawali pres.

Supriadi, Gito. 2011. Pengantar dan Tehnik Evaluasi Pembeajaran. Malang: Intimedia Press.

Suyanti, Retno Dwi. 2010. Strategi Pembelajaran Kimia. Medan: Graha Ilmu

Tatang, S. 2012. Ilmu Pendidikan. Bandung: Pustaka Setia

Tim penyususn. 2014. Pedoman Penulis Skripsi. Palangka Raya: Universitas Palangka Raya

Trianto. 2012. Mendesain Model Pembelajaran Inovatif Progresif, Konsep, Landasan dan Implementasinya pada Kurikulum Tingkat Satuan Pendidikan (KTSP). Jakarta: Kencana Prenada Media Group.

Valentie, I. 2019. Pemahaman Konsep Pereaksi Pembatas Hasil Pembelajaran Kimia Menggunakan LKS-Induktif Pada Siswa Kelas X. Jurnal Ilmiah Kanderang Tingang. 10, 1 (Jun. 2019), 12-26. 